\title{
FACTORS ASSOCIATED WITH COMPLEMENTARY FEEDING IN MALAKA TENGAH, EAST NUSA TENGGARA
}

\author{
Hery Dillak', Intje Picauly²), Mindo Sinaga3) \\ 1)BAPPEDA, Malaka Tengah District \\ 2)Masters Program in Public Health, Universitas Nusa Cendana \\ 3)District Health Office, Malaka Tengah, East Nusa Tenggara
}

\begin{abstract}
Background: The first two years of life provide a critical window of opportunity for ensuring children's appropriate growth and development through optimal feeding. Earlier studies reported that appropriate complementary feeding practices would result in $6 \%$ reduction in under-five mortality. This study aimed to determine factors associated with complementary feeding in Malaka Tengah, East Nusa Tenggara, using Theory of Planned Behavior.

Subjects and Method: This was a cross-sectional study conducted at Malaka Tengah district, East Nusa Tenggara, Indonesia, from January to August 2016. A total sample of 154 lactating mothers was selected for this study by simple random sampling. The dependent variable was complementary feeding. The independent variables were maternal knowledge, self efficacy, intention, and social cultural. The data were collected by questionnaire and analyzed by a multiple logistic regression. Results: Maternal knowledge $(b=0.17 ; 95 \% \mathrm{CI}=0.08$ to $0.73 ; \mathrm{p}=0.001)$, self efficacy $(b=0.24 ; 95 \% \mathrm{CI}=0.08$ to $0.73 ; \mathrm{p}=0.012)$, intention $(b=0.26 ; 95 \% \mathrm{CI}=$ 0.09 to $0.77 ; \mathrm{p}=0.015)$, and positive social cultural factor $(\mathrm{b}=0.09 ; 95 \% \mathrm{CI}=0.03$ to $0.27 ; \mathrm{p}<0.001$ ) had positive associations with complementary feeding.

Conclusion: Maternal knowledge, self efficacy, intention, and positive social cultural factor, have positive associations with complementary feeding.
\end{abstract}

Keywords: complementary feeding, knowledge, self efficacy, intention, social cultural

\section{Correspondence:}

Hery Dillak. Malaka District, East Nusa Tenggara, Indonesia.

Email: herydillakherydillak@yahoo.com. Mobile: 082237929309.

The 4th International Conference on Public Health

Best Western Premier Hotel, Solo, Indonesia, August 29-30, 2018 | 180 https://doi.org/10.26911/theicph.2018.03.11 